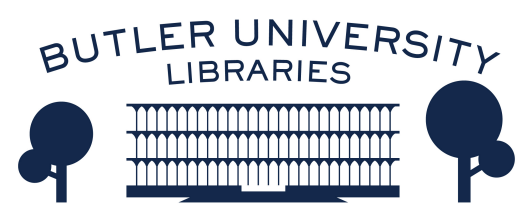

Journal of Hindu-Christian Studies

Volume 24

Article 22

November 2011

\title{
Book Review: "Margins of Faith: Dalit and Tribal Christianity in India"
}

Michelle Voss Roberts

Follow this and additional works at: https://digitalcommons.butler.edu/jhcs

Part of the Religion Commons

\section{Recommended Citation}

Roberts, Michelle Voss (2011) "Book Review: "Margins of Faith: Dalit and Tribal Christianity in India"," Journal of Hindu-Christian Studies: Vol. 24, Article 22.

Available at: https://doi.org/10.7825/2164-6279.1499

The Journal of Hindu-Christian Studies is a publication of the Society for Hindu-Christian Studies. The digital version is made available by Digital Commons @ Butler University. For questions about the Journal or the Society, please contact cbauman@butler.edu. For more information about Digital Commons @ Butler University, please contact digitalscholarship@butler.edu. 
improvisational, unpredictable, much like skilled jazz musicians responding to each other as the performance unfolds. The spontaneity of the interactions is important. It is one of a kind, not scripted. This is not an Aristotelian model where each nature has a telos.

Evil, intriguingly, is interference from outside the particular field where each being has its place. There can be violent rhythms. The question of evil seems to haunt the lectures. I am not sure that Panikkar addresses it in a satisfactory way although he constantly refers to a God who does not stop genocides. It is clear that there is a loss of some beings due to wars, CIA drone attacks, Twin Towers attacks and subway attacks which damage the Whole.

Helpfully, Panikkar says a rhythm has no natural ending because it carries time away with it, "all spatial metaphors break down"(46). In a clarification of rhythm, he notes that others can be stimulated or disturbed by my melody. The recent Gulf war will still "be felt a century from now $(54,351) . " \quad$ It too is part of the rhythm of Being, but it would be helpful if Panikkar could have unpacked what this "feeling" of past wars means for us. It might be possible to talk about the long-range impact of hateful ideologies here or about trauma and grief at the social and cultural level.

We memorialize and monumentalize and mediatize wars into a vast cultural imaginary. Troops are always "brave"; they always "sacrifice", and so on. Deep metaphors like the sacrifice of the "body" (324) for the "nation" might be a productive contrast to Panikkar's favored metaphor of inter-independence. What does something like the cosmotheandric body at war mean? Is this killing just a blip in one part of the cosmos? Panikkar is aware that vast cosmic perspectives can tend to distort axiologies (303). If we link this to the position that there is not a homogeneous time linking all universes (287), it is hard to see how a theodicy of some kind would come together. Mystically, Panikkar will state in another place that "there is an infinite value in satisfying someone's thirst" (300). Perhaps the being of the gesture itself is a Christophany. It seems that the gesture is part of the creative rhythm of the being and is itself salvation. It is hard to see how brave gestures balance horrific sufferings in the cosmic scheme.

Prabhu indicates that Panikkar wanted to address political connections in more depth but was unable to complete an analysis. As it stands, there are only passing references to things like anti-globalization movements and other protest movements but it is clear that they weigh in his scales as they keep surfacing .

Panikkar's scholarly voyage might have been the dramatic evocation of a reality that his followers still cannot see as well as he. He would say that evil does not triumph, but instead the ultimate melody is one of hope and humor and life. It is a magnificent orchestration, and so was he.

Michael McLaughlin

Saint Leo University

\section{Margins of Faith: Dalit and Tribal Christianity in India. Rowena Robinson and Joseph Marianus Kujur, editors. New Delhi: Sage Publications, 2010, viii +299 pp.}


tribal Christianities in India. Case studies on particular communities and regions impress upon the reader the true diversity of these groups. If it once seemed possible to generalize about the situation of Dalits or tribals - or even to lump them together as one-this is certainly no longer the case.

The editors' introduction frames the volume in terms of the multiple forms of marginality experienced by Dalit and tribal communities: geographical distance from the centers of power, discrimination by Hindus in society at large, discrimination by upper-caste Christians within the church, and discrimination by the state through the exclusion of Christians from benefits and protections for Scheduled Castes (3). The essay by Joseph Marianus Kujur then considers the "double marginalization" of tribal Christians vis-à-vis traditional culture and the church hierarchy (30). S.M. Michael's chapter continues this analysis by identifying the "fivefold discrimination" faced by Dalit Christians (54). The category of the margins is contested, however, by Jose Kalapura, who argues that it reifies a Eurocentric, colonial definition of Christianity. Instead, he defends Christianity as inherently diverse through a case study of the "continuum" of "old and new" elements in tribal Christian practice, which has begun to blur caste boundaries in eastern India (89). Lakshmi Bhatia finds a unique case in Mizoram, where the church has been "closely intertwined with the State" and is not marginalized in the same way as in other regions (169).

Regional and personal differences in how Indian Christians name themselves come to the fore in several essays. John C.B. Webster's study of five Dalit congregations in North India finds disagreement over whether to identify as Dalit. Most of the congregations Webster surveys reject the label for various reasons, including the upward economic and social mobility they have experienced in urban areas, or the idea that Christian identity replaces caste distinctions (114-115). By contrast, in David Mosse's study, Dalit Christians in Tamil Nadu claim a strong Dalit identity in line with their emphasis on liberation theology (236). In a complex case of intersecting identity markers, Ashok Kumar M. and Rowena Robinson observe that poor Dalit Lutherans in Andhra Pradesh practice Christianity but publicly declare themselves Hindu in order to access Scheduled Caste benefits such as education and protection under the Prevention of Atrocities Act of 1989 (158). Mathew Schmalz's essay traces one man's shifting self-identification and institutional affiliations, from Isai (Christian) to Dalit. Together, these chapters nicely illustrate the differing roles social location plays in Indian Christian identity formation.

Several excellent essays draw the factor of Hindu nationalism into this discussion. Peggy Froerer notes that certain "civilizing strategies" in present-day Christian missions among the Oraons "have succeeded in amplifying the cultural distance between local Christian and Hindu communities, thereby contributing to the emergence of Hindu nationalism in this area" $(121,120)$. At the same time, nationalist groups have taken up parallel "civilizing" tactics in their efforts to bring the tribal people up to the standards of caste Hindus (130). Lancy Lobo argues that "both evangelical Christian missionaries and Hindu Right activists are seeking to co-opt the tribals" (230). He notes, however, that the Catholic Church aims to preserve tribal culture to a much greater extent than the new Pentecostals do, a distinction that is overlooked by the Hindu Right. Mosse observes the challenge to "the work of 'Sanskritizing' theologians, architects, artists and the 1970s ashram movement" posed by the resurgence of Dalit identity in response to the pressures of Hinduization (254). Finally, Chad Bauman's documentation of recent HinduChristian conflicts in Orissa highlights how religion has become a much larger and deceptively stable identity marker than in the past (273-275). He interrogates the concept of "inducement" that has been central to charges against Christians and contends that "All conversions involve self-interest, as do all nonconversions" (284).

The focus of this collection lies in North and Central India, with essays on Dalits in Bihar (Kalapura), Andhra Pradesh (Kumar and Robinson) and North India in general (Webster, Schmalz, Michael); and on tribal Christians in Jharkhand (Kalapura), Mizoram (Bhatia), 
Gujarat (Lobo), Orissa (Bauman), and across central India (Kujur, Froerer). Only one essay is set specifically in South India (Mosse). An unfortunate omission, given the volume's concern with multiple margins, is any extended treatment of gender, a matter that Mosse observes is "cross-cut" by "divisions of caste" (256).

Each chapter presents a history of Christianity in the relevant region and analyzes current issues facing Dalit and tribal communities. This approach results in some overlap in historical and thematic material. The essays offer various levels of analytical depth. Some, like those of Michael, Kalapura, Bhatia, and Lobo, are valuable as general introductions to particular communities. Others, like the chapters by Kujur, Webster, Kumar and Robinson, and Schmalz, illustrate the diversity and complexity of Dalit and tribal Christian identities through sustained ethnographic reflection. The strong theoretical contributions of Kujur, Froerer, Mosse, and Bauman perhaps go farthest to accomplish the collection's stated goal, "to turn the lens on the contemporary and ever-changing face of Dalit and tribal Christianity, the different inflections in practice[,] and the shifts under the influence of political movements, identity assertion, cultural revivalism and attempts at the systematization of the paths of indigenization" (9).

Michelle Voss Roberts

Wake Forest University School of Divinity 